\title{
Retaining older workers: The effect of phased retirement on delaying early retirement
}

\author{
Åsmund Hermansen \\ Fafo Institute for Labour and Social Research \\ Email: ahe@fafo.no
}

\begin{abstract}
Introduction: Phased retirement involves reducing working time in the final years before retirement. The aim of phased retirement is to extend working careers and retain older workers who would otherwise opt for full early retirement. This article investigates the effect of offering phased retirement on early-retirement behaviour in Norway.

Method: The data used in the analysis covers the period between 2000 and 2010 and comprises all employees between 61 and 62 years of age $(\mathrm{N}=18$ 174) who were employed in any of the 442 companies that participated in a 2010 survey carried out by the Fafo Institute for Labour and Social Research and Respons Analyse AS, a Norwegian research firm. I use a difference-indifferences approach and logistic regression, which enables the measurement of changes in the individual relative risk of retiring full-time on the contractual pension (AFP, avtalefestet pensjon, contractual early-retirement pension,) before and after the introduction of phased retirement as a retention measure.

Results: The results show that working in a company that offers reduced working hours for older workers does not have an effect on the relative risk of a 61- or 62-year-old withdrawing a full contractual pension in the next two years of their employment. This result is evident both before and after controlling for a range of known individual risk factors, as well as after controlling for company characteristics.

Discussion: In the search for suitable measures for retaining older workers, offering phased retirement may still be part of the answer. Though my analysis does not support the idea that more flexible working hours is a decisive factor for those who choose to opt for full early retirement, a possible next step could be to investigate the impact of offering flexible working hours on the employment duration of those who do remain in employment.
\end{abstract}

Keywords: Difference-in-differences, early retirement, older workers, retention measures, phased retirement 


\section{Introduction and research question}

Reducing early retirement and prolonging employees' working careers are important to the future of the welfare state. A large number of persons outside the labour market give rise to great political concern because it erodes the funding basis of the welfare-state system. Succeeding in reducing the number of early retirees as the population ages calls for polices and measures that prolong employees' working careers (Midtsundstad, Hermansen, \& Nielsen, 2012; Taylor, 2011). In the European Union, the so-called Lisbon Strategy led to the 'Barcelona target' in 2002, which demanded that every EU member state seek an increase in average retirement age of about five years by 2010 (Hofäcker, 2010). The increased attention to the ageing part of the workforce in Norway is manifested through the Inclusive Working Life Agreement (The IWLA) which set out to increase the average age of retirement (2001-2010) and from 2010 to increase the total years in employment. With the signing of the IWLA in 2001, the Norwegian government called for employers to take greater social responsibility for keeping people in employment until they reach pensionable age. They thus acknowledged, as many other European countries have done, that it is changes to employers' policies that can drive a significant change in retirement behaviour (Vickerstaff, Cox, \& Keen, 2003).

The increased attention on the employer's role in reducing early retirement has fostered a growing interest in measures for retaining older workers both in the EU and Norway (Taylor, 2006). Since the signing of the IWLA in 2001, offering older workers the possibility of reducing their working hours in the final years before retirement has increased in popularity in Norway. Almost 20 per cent of Norwegian companies with ten or more employees offered their older workers such an arrangement in 2010 (Midtsundstad \& Bogen, 2011). Several studies have suggested that flexible working hours can have a positive effect on the labour supply of older workers, providing a more phased transition into retirement and thereby extending the working career of older employees (Bredgaard \& Tros, 2006; Delsen, 1996; Gielen, 2009; Johnson, 2011; Taylor, 2006; Wadensjö, 2006). Despite the recognition of phased retirement as an effective means of increasing the labour supply of older workers, research into the efficacy of reducing working hours as a retention measure is limited in Norway. The aim of my study is to examine whether offering phased retirement has an effect on the relative risk of retiring full-time on the contractual pension. 
The few Norwegian studies investigating the impact of retention measures on early-retirement behaviour show that the existing measures in 2005 did not always help to delay retirement (Midtsundstad, Hermansen, \& Nielsen, 2012; Midtsundstad, Nielsen, \& Hermansen, 2012). However, the aim of these studies was not to evaluate the impact of individual retaining measure, such as phased retirement, but to evaluate the overall effect of being offered retention measures. Furthermore, very few companies had initiated such measures by 2005 compared with the 2010 situation (Midtsundstad, Hermansen, \& Nielsen, 2012; Midtsundstad, Nielsen, \& Hermansen, 2012). Hence, further analysis of the effects of the measures used by companies to retain older workers is needed.

\section{Previous research}

Reducing early retirement and increasing employees' working careers has been on the policy agenda for many years (Disney, 1996; EspingAndersen, 2000; Meier \& Werding, 2010). In contrast to the many alleged advantages brought about by phased retirement, measures promoting a smooth transition between full employment and full retirement are rare in most countries. Thus, research on the laboursupply effects of these measures in respect of retaining older workers is limited (Graf, Hofer, \& Winter-Ebmer, 2011; Hutchens \& GraceMartin, 2006; Taylor, 2006).

Studying phased-retirement policies in Denmark, Finland and Sweden, Delsen (1996) argues that only the Swedish programme, which was abolished in 2001, can be considered successful with regard to reducing the number of early retirees. According to Delsen, part-time employment helped to reverse a negative trend in the labour-market participation rate of older workers. Compared to Denmark and Finland, the crucial conditions making phased retirement a success in Sweden were an adequate supply of part-time jobs and financial incentives for continuing working. The Danish programme was inspired by the Swedish, but unfavourable labour market conditions, in the form of a recession, and a generous earlyretirement scheme meant the programme was less successful (Delsen, 1996). The same factors limited the success of the Finnish phased-retirement scheme, in addition to the fact that pensioners had difficulties finding part-time work. According to these experiences, 
labour-market conditions, the supply of part-time jobs, the impact of part-time employment on pension entitlements and the existence of generous retirement schemes all seem to be important factors determining the success or failure of phased-retirement schemes (Delsen, 1996; Latulippe \& Turner, 2000; Redaymulvey, 2000).

Evaluating the subsidized Austrian Old-Age Part-Time Scheme introduced in 2000, Graf et al. (2011) find the scheme to have a negative impact on labour supply among older workers. Their analysis indicates that workers who would normally work full-time change to part-time, resulting in an overall decrease in the labour supply among older workers. These findings are supported by a Norwegian study by Becken (2011), which reveals subsidizing reduced working hours to older employees in four Norwegian public agencies to have a negative effect on labour supply. Other studies reach the same conclusion: subsidizing reduced working hours induces a larger number of those who would have otherwise continued working full-time to reduce their working hours (Hilsen \& Salomon, 2010; Midtsundstad \& Bogen, 2011).

Several studies have shown that a considerable proportion of older workers emphasize reduced working hours as a decisive factor in the decision to prolong their working career (Midtsundstad, 2006, 2009; Midtsundstad \& Nielsen, 2013; Reichborn-Kjennerud, Gamperiene, \& Hilsen, 2011). Similarly, Charles and DeCicca (2007) reveal that older American workers who are not free to lower their usual working hours, that is, workers who are hours-constrained or over-employed, are much more likely to retire than workers who are free to adjust their hours of work. Using the three first waves of the Health and Retirement Study (1992 to 1996), Charles and DeCicca show that these findings hold true for both sexes, but the lack of flexibility had the greatest effect on men.

Studying the presence of constraints of hours in the labour market in the United Kingdom, Gielen (2009) finds that some over-employed women in the UK, especially those working full-time, leave the labour market early owing to a lack of gradual retirement opportunities with their current employer. However, the study was unable to investigate whether more flexibility would actually increase the labour supply of older workers. According to Gielen, increasing flexibility may increase total hours worked as a result of increased participation, but this might be offset by shorter hours among previously hours-constrained workers. 
Using data from the Health and Retirement study, Gustman and Steinmeier (2004) have used simulations to yield insight into the effect of abolishing minimum-hours constraints. Abolishing minimum-hours constraints significantly increases the number of partially retired workers, reducing full-time employment among older workers and resulting in a small net increase in labour supply. Wadensjö (2006) reaches the same conclusion in his study of the abolished Swedish phased-retirement scheme. The scheme had a positive effect on the labour supply of older workers (number of hours worked), especially among women. The positive effect of people working part-time instead of retiring early outweighed the negative effect of reduced working hours among those who would have otherwise continued working fulltime until normal retirement age.

Boockmann et al. (2012) have analysed longitudinal employeremployee data for German ${ }^{1}$ companies in order to investigate the effect of age-specific part-time work among older workers. Up until 2009 the German Federal Employment Agency paid subsidies to employers offering age-specific part-time work to employees aged 55 and over. The results of this study indicate that offering part-time work to older workers tended to reduce the duration of employment among workers between age 58 and 63 .

The existing studies on phased retirement exhibit mixed results and do not allow us to draw universally applicable conclusions. The effect of offering phased retirement on labour supply seems to vary with labour-market conditions, the supply of part-time jobs, the impact of part-time employment on pension entitlements, and the existence of generous retirement schemes (Delsen, 1996; Latulippe \& Turner, 2000; Redaymulvey, 2000). Boockmann et al. (2012) conclude that the search for suitable retention measures which utilize the potential of older workers must continue. More research is needed before we can draw any conclusions as to 'what works in age management' (p. 21).

\footnotetext{
${ }^{1}$ The analysis is based on survey information for 1063 West German establishments between 2000 and 2002. The establishment data is linked with retrospective register data on all employees between ages 40 and 65, providing information on employment durations observed back to 1975. East German establishments are excluded from their analysis, owing to missing data before the 1990s.
} 


\section{Method}

The data used in this analysis covers the period between 2000 and 2010 and comprises all employees between 61 and 62 years of age $(\mathrm{N}=18$ 174) who were employed in any of the 442 companies that participated in a 2010 survey. The survey was conducted by the Fafo Institute for Labour and Social Research and Respons Analyse AS, a Norwegian research firm, in the period August to September 2010. The sample was representative for all Norwegian companies with ten or more employees in 2010, and one or more employees between 61 and 62 years of age. The survey provides information on company characteristics and whether reduced working hours is used as a retention measure and, if so, in which year the measure was introduced (Midtsundstad \& Bogen, 2011). All information on individual employees has been provided by Statistics Norway (SSB) and is drawn from administrative registers.

In my analysis, I investigate whether, in the period 2000 to 2008 , the introduction of phased retirement affected the relative risk of workers aged 61 and 62 fully retiring on the contractual pension in the next two years of their employment. The contractual pension (contractual early retirement pension AFP) offered older workers the possibility of opting for early retirement between the ages of 62 and 66 in the timespan investigated in this article. ${ }^{2}$ Early retirement was available to all publicsector workers and about 40 per cent of private-sector workers (the scheme was optional for private-sector companies) (Nergaard, 2009). Of the 442 companies included in the analysis, 135 companies are in the public sector and 307 are in the private sector. All of the private sector companies I include in the analysis offer the contractual pension (contractual early retirement pension AFP) to their employees.

\section{Difference-in-differences}

In my analysis, I use a difference-in-differences approach which enables the measurement of changes in the individual relative risk of fully retiring on the contractual pension before and after the

\footnotetext{
${ }^{2}$ From the 1 st of January 2011 the contractual early-retirement scheme was changed to a flexible lifelong annuity for private-sector workers, making the scheme distinctly different from the scheme in the public sector, which is still designed as an early-retirement scheme. Nevertheless, this regulatory change was implemented after the timespan investigated in this article.
} 
introduction of reduced working hours. This is a standard method for measuring the effects of interventions and regulatory changes. The method consists of comparing two groups, where one group experiences a policy change or intervention during the period under consideration. In my analysis, the introduction of reduced working hours as a retention measure represents the policy change or intervention (Angrist \& Pischke, 2008; Wooldridge, 2005, 2009).

I investigated whether offering phased retirement impacts the individual relative risk of withdrawing a full contractual pension. These differences in average change are also referred to as a difference-indifferences estimator (Angrist \& Pischke, 2008; Wooldridge, 2009). Given that the dependent variable is binary categorical, I use logistic regression in the analysis and I report odds ratios. I have also estimated the two models as linear probability models, obtaining substantially similar results (not shown).

All my analyses were performed using Stata, version 12. In model 1, I investigate the total effect of offering phased retirement. To be able to investigate the total effect I have included the retention measure as a dummy variable, a dummy for separating the pre-treatment period (0) and post-treatment period (1), measuring the overall change and the interaction between the change and the retention measure (differencein-differences estimator). Thus, in model 1 , I estimate the gross effect of offering phased retirement. However, it is very unlikely that companies offering phased retirement are identical to those without such a measure in all other respects, and that the employees working in companies offering phased retirement are identical to those in companies without the measure. Thus, in model 2, I control for various individual and company characteristics which may vary between the intervention and control group.

The measurement of phased retirement which I apply in this article is based upon the HR manager/executive director in the surveyed sample of companies reporting to have made it possible for workers to opt for reduced working hours from the age of 62, thereby facilitating phased retirement (Midtsundstad \& Bogen, 2011). Hence, the measurement of phased retirement I use in this article is based on a reduction in weekly or annual working hours for older workers aged 62 and above, continuing with their current employer. The measurement I use includes arrangements where the reduction is subsidized as well as those where it is not, the former comprising 65 per cent of the treatment group and the latter 35 per cent. 
The number of companies offering phased retirement was quite low prior to 2005, with less than two per cent of the companies surveyed offering reduced working hours. The measure increased in popularity from 2005, with more than six per cent of the companies offering reduced working hours by 2006, increasing further still to 18.6 per cent in 2010. To make a clear delimitation between the pre- and posttreatment period I have chosen to include only those companies which initiated reduced working hours as a retention measure from 2005. Thus, I investigate the relative risk of 61 - and 62 - year- olds retiring in the next two years of their employment during a period when none of the companies in my data had initiated this retention measure, compared with the relative risk of retiring during a period when a known selection of the companies had introduced such a measure. I refer to the first period, $2001 / 2002$ to $2004 / 2005$ as the pre-treatment period, and to the second period, 2005/2006 to 2009/2010, as the post-treatment period.

Offering phased retirement is a choice made by each individual company and thus the group of Norwegian companies offering this retention measure is self-selected. However, I find it reasonable to assume that the distribution of older employees between the intervention and the control group is random. I base this assumption on the fact that very few change jobs after the age of 60 , enabling them actively to seek out companies with such retention measures for older workers (Lien, 2013; OECD, 2013). However, in order to be able to measure the true effect of providing phased retirement, I must assume that the two groups are comparable over time. Such comparability is not very likely, thus I control for a range of individual and company characteristics. Including these individual and company characteristics allows me not only to control for differences between the two groups, but also to control for known factors associated with early retirement.

\section{Factors associated with early retirement}

Understanding the transition from work to retirement and the role played by phased retirement as a retention measure rests on our ability to recognize the variety of factors influencing early-retirement practices. Whether an early exit from working life is voluntary or involuntary and whether it is mainly affected by labour supply or labour 
demand are two related and central questions within the debate on early retirement (Jensen \& Øverbye, 2013; Midtsundstad, 2013).

Working on the assumptions that individuals desire to maximize their lifetime earnings and that the exit of older workers from the labour market is voluntary and mainly affected by labour supply, economic studies primarily place the emphasis on financial incentives 'pulling' employees out of working life early (Engelhardt, 2012; Gambetta, 1987; Gruber \& Wise, 2007, 2010; Hernæs, Røed, \& Strøm, 2002). To account for the effect of financial incentives presumably 'pulling' older workers into early retirement, I included 'income percentile' (net income after tax divided into percentiles); 'spouse income percentile' (spouse income after tax divided into percentiles) and 'household debts percentile' (household debts divided into percentiles) in the analysis.

Contradicting the emphasis on free individual choice and 'pull-factors', a growing research literature is focusing on involuntary retirement as a result of 'push-factors' and labour demand. This includes 'labour market and company-level push factors' such as structural adjustments, rationalization, increased eligibility requirements, and other factors that 'push' elderly, less productive or less skilled workers out of the labour market (Halvorsen 1977; Gambetta 1987; Dorn and Sousa-Poza 2010). Referred to as 'individual push factors', health problems as well as physical and mental strains related to the job have proven to increase the relative risk of older workers opting for early retirement (Buchholz, Hofäcker \& Blossfeld 2006; Midtsundstad 2006; Börsch-Supan, Brugiavini, \& Croda 2009; Engelhardt 2012; Gørtz 2012; Calvo, Sarkisian \& Tamborini 2013).

One of the limitations of the data I apply in the analysis is the lack of variables controlling for differences in health, working environment, and conditions between the intervention and control group. However, controlling for 'sick absence', 'level of education', 'occupation', and 'industry' does presumably capture important aspects of differences in health, working environment, and conditions between the intervention and control group. Thus, I included 'sick absence' ('sickness absence' certified by a physician and lasting for more than 16 days, 'no sick absences' (ref.)) and 'level of education' divided into 'elementary school' (ref.), 'secondary school', 'undergraduate from university/college' and 'postgraduate from university/college' in the analysis. The classification of the different occupations I use is based on the Erikson-Goldthorpe social class schema, using the 
International Standard Classification of Occupations (ISCO88) which distinguishes between 'workers', 'routine non-manual employees' and 'professionals, administrators, and officials' (ref.) (Leiulfsrud, Bison, \& Jensberg, 2005). To control for type of 'industry' in the analysis, I included the following: 'public administration' (ref.), 'other industries', 'teaching', 'health and social services', 'manufacturing', 'construction', 'hotels and restaurants', and 'wholesale and retail trade'.

As I have illustrated in Table 1 (below), the intervention group has a higher proportion of employees with 'elementary school' as their highest 'level of education' and a lower proportion with 'undergraduate from university/college' than the control group. The intervention group also has a higher proportion working in 'public administration' and 'other industries'. Hence, I also included 'level of education' and 'industry' to control for the differences between the intervention and control group.

Older employees working full-time may feel a greater need to reduce working hours in the final years of their career than those working part-time and thus have a higher relative risk of opting for phased retirement than employees already working part-time. To account for the effect of working hours, I included contractual working hours, that is, 'full-time' (ref.), 'long part-time' (from 50 to $80 \%$ full-time equivalent), and 'short part-time' (less than $50 \%$ full-time equivalent) in the analysis.

Table 1. Distribution by independent variables

\begin{tabular}{|c|c|c|c|c|}
\hline & \multicolumn{2}{|c|}{$2001 / 2002-2004 / 2005$} & \multicolumn{2}{|c|}{$2005 / 2006-2009 / 2010$} \\
\hline & $\begin{array}{l}\text { Intervention } \\
\text { group }\end{array}$ & $\begin{array}{l}\text { Control } \\
\text { group }\end{array}$ & $\begin{array}{l}\text { Intervention } \\
\text { group }\end{array}$ & $\begin{array}{l}\text { Control } \\
\text { group }\end{array}$ \\
\hline Woman & 65.6 & 62.3 & 60.1 & 62.1 \\
\hline Living in a one-person household & 18.8 & 20 & 19.4 & 21.4 \\
\hline Sick absence & 20.2 & 16.5 & 13.8 & 12.2 \\
\hline Elementary school & 25.8 & 21.5 & 22.1 & 14.2 \\
\hline Secondary school & 43.2 & 44.3 & 49.6 & 39.1 \\
\hline Undergraduate from university/college & 24.7 & 25.6 & 19.9 & 34.9 \\
\hline Postgraduate from university/college & 6.3 & 8.6 & 8.4 & 11.8 \\
\hline
\end{tabular}




\begin{tabular}{|c|c|c|c|c|}
\hline $\begin{array}{l}\text { Income percentile, mean } \\
\text { (s.d.) }\end{array}$ & $\begin{array}{c}46.2 \\
(29.1)\end{array}$ & $\begin{array}{l}51.9 \\
(28.5)\end{array}$ & $\begin{array}{c}46.6 \\
(29.4)\end{array}$ & $\begin{array}{l}53.1 \\
(28.4)\end{array}$ \\
\hline Spouse income percentile, mean (s.d.) & $\begin{array}{c}42.7 \\
(30.5)\end{array}$ & $\begin{array}{c}43.2 \\
(31.3)\end{array}$ & $\begin{array}{c}43.5 \\
(30.1)\end{array}$ & $\begin{array}{c}46.2 \\
(33.1)\end{array}$ \\
\hline Household debts percentile, mean (s.d.) & $\begin{array}{c}36 \\
(29.6)\end{array}$ & $\begin{array}{c}39.9 \\
(29.5)\end{array}$ & $\begin{array}{c}44.7 \\
(29.5)\end{array}$ & $\begin{array}{c}40.2 \\
(28.3)\end{array}$ \\
\hline $\begin{array}{l}\text { Spouse retired on AFP } \\
\text { retirement scheme }\end{array}$ & 7.5 & 7.3 & 6.8 & 5.8 \\
\hline Spouse retired on disability pension & 16.9 & 15.9 & 16.5 & 13.6 \\
\hline Full-time 30 hours or more & 64.4 & 69.7 & 70.8 & 72.7 \\
\hline Part-time $20-29$ hours & 16.3 & 14.4 & 13.2 & 13.5 \\
\hline Part-time $<20$ hours & 19.2 & 15.9 & 16 & 13.8 \\
\hline Worker & 64.2 & 42.6 & 50 & 34.7 \\
\hline Routine non-manual employee & 14 & 39.9 & 20 & 40 \\
\hline Professional, administrator or official & 21.8 & 17.6 & 30.1 & 25.3 \\
\hline 100 or more employees & 83.9 & 82.8 & 88.8 & 84.7 \\
\hline Human resources manager & 97.9 & 91.1 & 97 & 92.3 \\
\hline Public administration & 16.2 & 10.3 & 18.8 & 7.7 \\
\hline Other industries & 16.1 & 8.2 & 27.1 & 8.6 \\
\hline Teaching & 38.6 & 28.1 & 15.9 & 33.9 \\
\hline Health and social services & 22 & 27.7 & 20.9 & 27.8 \\
\hline Manufacturing & 4.7 & 12.6 & 6.2 & 10.7 \\
\hline Construction & 2.2 & 4.3 & 1.7 & 2.9 \\
\hline Hotels and restaurants & 1.1 & 2.6 & 1.3 & 2.1 \\
\hline Wholesale and retail trade & 1.7 & 7.2 & 4.2 & 2 \\
\hline Not IWLA-company & 28.4 & 41.3 & 33.5 & 57.6 \\
\hline IWLA-company 2001 & 4.9 & 11.2 & 7.3 & 8.7 \\
\hline IWLA-company 2002-2010 & 66.7 & 47.5 & 59.2 & 33.7 \\
\hline $\mathrm{N}$ & 3986 & 3870 & 3624 & 6694 \\
\hline
\end{tabular}

In the analysis I also included confounders controlling for whether the employees work in a company with '100 or more employees' ('less than 100 employees', ref.) and whether the company has a 'human resources manager' ('no human resources manager', ref.). Larger 
companies are presumably more flexible since they have a large workforce, which provides greater leeway for offering flexible working hours. The human-resources manager holds an important role in facilitating working conditions which safeguard the needs of employees and advocates adaptions to account for these needs. As I have shown in Table 1, the intervention group has a slightly larger proportion employed in companies with a human-resources manager, thus I also included the confounder to control for this difference.

Studies show that retirement practices vary according to individual circumstances, such as gender, and experiences outside the workplace, such as family situation and spouse retirement behaviour, referred to as 'jump-factors' (Hallberg, 2007; Hank, 2004; Hauge \& Årethun, 2008; Midtsundstad, 2002, 2005a; Oude Hengel, Blatter, Geuskens, Koppes, \& Bongers, 2012). To account for gender and possible jump-factors I included 'woman' ('male', ref.), 'living in a oneperson household' ('not living in a one-person household', ref.), 'spouse retired on the contractual pension' ('no spouse or spouse not retired on the contractual pension', ref.) and 'spouse retired on disability pension' ('no spouse or spouse not retired on disability pension', ref.) in the analysis.

Companies that have signed the Inclusive Working Life Agreement presumably have a greater focus on supporting and motivating older workers to continue working. From 2006, all IWLA-companies were also obligated to formulate an active ageing policy (Midtsundstad \& Bogen, 2011). To account for working in an IWLA-company and when the company signed the Inclusive Working Life Agreement, I include 'IWLA-company 2001' and 'IWLA-company 2002-2010' ('not IWLAcompany', ref.) in the analysis.

\section{Results}

I have illustrated the early-retirement behaviour for the period and companies under consideration in Figure 1 below. Employing a difference-in-differences approach rests on an assumption that the underlying trends in the outcome variable would be the same in the absence of treatment (Angrist \& Pischke, 2008). As I illustrate in Figure 1, the number of employees withdrawing a full contractual pension is quite similar for both groups in the pre-treatment period from 2001/2002 to 2004/2005. Thus, I argue that Figure 1 provides 
visual evidence of an equal underlying trend in the pre-treatment period.

Figure 1. Percentage of 61- and 62-year-olds withdrawing a full contractual pension in the next two years of their employment working in companies offering phased retirement as a retention measure compared with the percentage working in companies without such an arrangement for older workers.

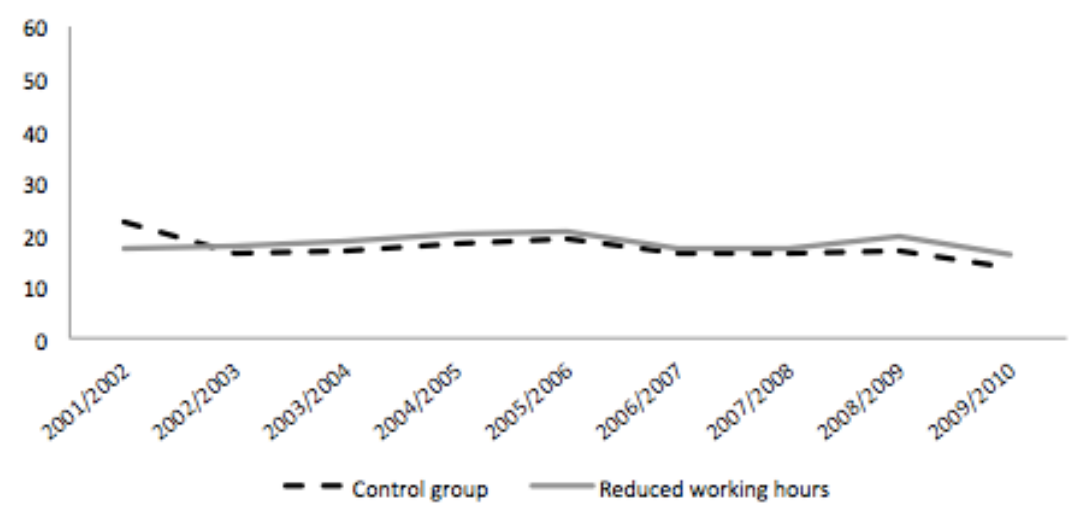

In the post-treatment period from 2005/2006 to 2009/2010, the earlyretirement figures are also quite similar. However, the early-retirement figures in the treatment group do not seem to be significantly different from the figures in the control group. One would expect the figures to be significantly different if reduced working hours have an impact on the relative risk of withdrawal of a full contractual pension. Nevertheless, in the analysis I have investigated the changes in the individual relative risk of withdrawing a full contractual pension and not the changes in the companies' numbers of early retirees, as I have illustrated in Figure 1.

In addition, I have performed a 'placebo difference-in-differences' test (not shown) as a check for robustness to investigate the trends in Figure 1. In the placebo test I simulated that reduced working hours were initiated among the intervention companies from 2003 and not from 2005 onwards. I used 2001/2002 to 2002/2003 as the pretreatment period and $2003 / 2004$ to $2004 / 2005$ as the post-treatment period. The placebo difference-in-differences did not yield significant 
results, thus strengthening my assumption that the trends were quite similar in the pre-treatment period and that there were no unobserved trends affecting one of the groups but not the other.

As I have illustrated in Table 1, the proportion of workers with 'elementary school' as their highest level of education, the proportion of 'workers', and the proportion working in a 'non IWLA-company' change significantly in the control group from the pre-treatment to the post-treatment period. Also, in the treatment group, the proportion working in 'other industries' changes significantly from the pretreatment to the post-treatment period. To control for these changes I have re-estimated the analysis and included interactions between the respective confounders and the dummy for change from the pretreatment to the post-treatment period (not shown). To control for clustered data on company level, I have also performed a regression using clustered standard errors (not shown). The regression results using clustered standard errors and including these interactions did not differ from the results which I have presented in Table 2 (below) using normal standard errors and not including the respective interactions.

Table 2. Individual relative risk of withdrawing a full contractual pension among 61- and 62-year-olds in the next two years of employment, having been exposed to reduced working hours as a retention measure, before and after controlling for a range of individual and company characteristics. $\mathrm{OR}=$ odds ratio.

$\begin{array}{lll} & \text { Model 1 } & \text { Model 2 } \\ \text { Woman } & \text { OR } & \text { OR } \\ \text { Living in a one-person household } & .787^{\star \star \star} \\ \text { Sickness absence } & .804^{\star \star \star} \\ \text { Elementary school (ref.) } & 1.608^{\star \star \star} \\ \text { Secondary school } & 1.000 \\ \text { Undergraduate from university/college } & .868^{\star \star \star} \\ \text { Postgraduate from university/college } & .674^{\star \star \star} \\ \text { Income percentile } & .406^{\star \star \star} \\ \text { Spouse income percentile } & .994^{\star \star \star} \\ \text { Household debts percentile } & 1.006^{\star \star \star} \\ \text { Spouse retired on contractual pension } & .993^{\star \star \star} \\ \text { Spouse retired on disability pension } & 1.495^{\star \star \star} \\ \text { Part-time <20 hours (ref.) } & 1.092 \\ \end{array}$




\begin{tabular}{|c|c|c|}
\hline \multicolumn{2}{|l|}{ Part-time $20-29$ hours } & $2.039^{\star \star \star}$ \\
\hline \multicolumn{2}{|l|}{ Full-time 30 hours or more } & $1.780^{\star \star *}$ \\
\hline \multicolumn{2}{|l|}{ Professional, administrator or official (ref.) } & 1.000 \\
\hline \multicolumn{2}{|l|}{ Routine non-manual employee } & 1.120 \\
\hline \multicolumn{2}{|l|}{ Worker } & .940 \\
\hline \multicolumn{2}{|l|}{ Less than 100 employees (ref.) } & 1.000 \\
\hline \multicolumn{2}{|l|}{100 or more employees } & $1.190^{\star * *}$ \\
\hline \multicolumn{2}{|l|}{ No human resources manager (ref.) } & 1.000 \\
\hline \multicolumn{2}{|l|}{ Human resources manager } & 1.056 \\
\hline \multicolumn{2}{|l|}{ Public administration (ref.) } & 1.000 \\
\hline \multicolumn{2}{|l|}{ Other industries } & $2.984^{\star \star \star}$ \\
\hline \multicolumn{2}{|l|}{ Teaching } & $2.194^{\star \star \star}$ \\
\hline \multicolumn{2}{|l|}{ Health and social services } & $1.282^{\star \star \star}$ \\
\hline \multicolumn{2}{|l|}{ Construction } & $2.745^{\star \star \star}$ \\
\hline \multicolumn{2}{|l|}{ Manufacturing } & $4.933^{\star * *}$ \\
\hline \multicolumn{2}{|l|}{ Hotels and restaurants } & $3.755^{\star \star \star}$ \\
\hline \multicolumn{2}{|l|}{ Wholesale and retail trade } & $2.562^{\star \star *}$ \\
\hline \multicolumn{2}{|l|}{ Not IWLA-company (ref.) } & 1.000 \\
\hline \multicolumn{2}{|l|}{ IWLA 2001} & $1.184^{\star \star}$ \\
\hline \multicolumn{2}{|l|}{ IWLA 2002-2010 } & $1.156^{\star \star \star}$ \\
\hline Retention measure - reduced working hours & 1.012 & 1.037 \\
\hline $\begin{array}{l}\text { Change from pre-treatment period to post-treatment } \\
\text { period }\end{array}$ & .814 & .913 \\
\hline $\begin{array}{l}\text { Retention measure* change (difference-in-differences } \\
\text { estimator) }\end{array}$ & 1.137 & .964 \\
\hline Pseudo R² & .001 & .077 \\
\hline $\mathrm{N}$ & 18174 & 18174 \\
\hline
\end{tabular}

${ }^{* *}: p \leq 0.05,{ }^{* * *}: p \leq 0.01$

The analysis shows that offering 61- and 62-year-olds reduced working hours has no significant effect on the relative risk of withdrawing a full contractual pension in the next two years of employment. The lack of an effect is evident both before (model 1) and after controlling for the selected individual and company characteristics (model 2). I find almost no change in the difference-indifferences estimator when controlling for the different confounders. I have done a re-estimation, delimiting the treatment group to only those with a subsidized reduction in working hours, excluding those with an unsubsidized reduction (not shown). The re-estimated results are the same, offering reduced working hours does not affect the 
relative risk of withdrawing a full contractual pension among 61 - and 62 -year-olds in the next two years of their employment. Thus, the results provide evidence for phased retirement having no impact on the individual relative risk of withdrawing a full contractual pension.

\section{Discussion}

The results I have presented in this article show that working in a company that offers reduced working hours for older workers does not have an effect on the relative risk of a 61- or 62-year-old withdrawing a full contractual pension in the next two years of their employment. This result is evident both before and after controlling for a range of known individual risks, as well as after controlling for company characteristics. Thus, the lack of an effect of reduced working hours cannot be ascribed to differences in these respects between individuals working in intervention companies and those working in the companies that constitute the control group.

I must emphasize that the analysis is based on information about whether the companies have introduced the reduced working hours as a measure for retaining older workers, and not information about whether older employees actually opt to reduce their working hours. Thus, my analysis is based on the initial treatment assigned and not on the treatment actually received, known as intention to treat analysis. Nevertheless, the possibility of reduced working hours is available to all employees from the age of 62 years. Thus, I find it quite unlikely that a large proportion of the employees in the treatment group have not been faced with the possibility of opting for phased retirement when deciding whether or not to make an early exit.

The existing research on phased retirement does not allow universally applicable conclusions to be drawn. The results differ according to labour-market conditions, the supply of part-time jobs, the impact of part-time employment on pension entitlements and the existence of generous retirement schemes (Delsen, 1996; Latulippe \& Turner, 2000; Redaymulvey, 2000). Using phased retirement as a retaining measure implies by definition that companies offer older workers the possibility of entering part-time work. Furthermore, opting for phased retirement - combining part-time work and partial retirement - will provide higher financial rewards than withdrawing a full contractual pension. Thus, I find it reasonable to assume that such an arrangement reduces the attractiveness of withdrawing a full 
contractual pension. Thus, the lack of an effect of offering phased retirement on the withdrawal of a full contractual pension does not necessarily stem from constraints in the supply of part-time possibilities or generous retirement schemes.

It needs to be emphasized that the Norwegian labour market was characterized by low levels of unemployment during the vast part of the period which I have investigated. When the financial crisis hit in 2009 , the number of unemployed increased somewhat, yet marginally compared with the rest of Europe (NAV, 2014; Eurostat, 2014). Delsen (1996) concludes, as previously mentioned, that the Danish and Finnish phased-retirement programmes failed, among other reasons, because of unfavourable labour-market conditions, in the form of a recession. Thus, on the basis of the experiences from Denmark and Finland, $I$ find it reasonable to assume that the worsening labour-market conditions following the financial crisis would not have changed the results presented in this article. Even though I studied a period with quite favourable labour-market conditions, my results demonstrate that phased retirement does not have an impact on early-retirement behaviour.

I find it reasonable to assume that reduced working hours reduce psychical and mental strains in the final phase of working life, providing older workers with the possibility to reconcile a wish for more leisure time and to continue working. Surveys show that two out of ten early retirees in Norway justify an exit to full retirement on the basis of a lack of working time flexibility (Midtsundstad, 2002, 2005b; Midtsundstad \& Nielsen, 2013). Two out of ten Norwegian employees also express that combining part-time work and part-time retirement is difficult at their workplace (Dalen, 2012). Thus, providing older overemployed workers with the possibility of a smooth transition between full-time work and full-time retirement may have a significant impact as a retention measure. Nevertheless, the results in this article do not support the notion that offering phased retirement may reduce overemployment among older workers or have a positive effect on the labour supply. However, these surveys also show that the need for more leisure time, physical and mental strains related to the job, health problems, and loss of interest and motivation are emphasized as reasons to retire by early retirees to a greater extent than a lack of working time flexibility (Midtsundstad, 2005a; Midtsundstad \& Nielsen, 2013). Thus, the possibility of opting for phased retirement may simply not be enough to discourage early retirees from withdrawing a full contractual pension if they also experience physical and mental 
strains at work, health problems, or a loss of interest and motivation. Justifying an exit to full-time retirement on the basis of a lack of working time flexibility may be just one of many reasons and not the reason for leaving the labour market altogether (Midtsundstad, 2002, 2005b; Midtsundstad \& Nielsen, 2013).

The data I have used in this article consists exclusively of older workers above the age of 60 years. These workers are a select group compared with the population of older workers as a whole, since a large proportion of employees retire on the disability pension before they turn 60 (Midtsundstad, Hermansen, \& Nielsen, 2012). I cannot rule out the possibility that other facilitation measures involving some sort of work time reduction would be different for other age groups. Thus, the results from this analysis cannot be generalized outside the age group investigated in this article. Midtsundstad, Hermansen, \& Nielsen (2012) emphasize that the age requirement for eligibility to retaining measures, such as phased retirement, appears to be excessive in some industries (62 years). Workers who become disabled before reaching the age requirement and who may have been the most in need of facilitation will not benefit from these measures.

The results must be interpreted with caution, given the fact that the data I have used in my analysis lack of possibility of controlling for factors related to health status, working environment, and working conditions. Thus, I cannot rule out the possibility that the health status of older workers, the working conditions, and the working environment in companies that offer reduced working hours are on the whole less favourable than in companies that do not provide reduced working hours. Thus, in not controlling for health status, working environment and conditions it might be that I have underestimated the effect of reduced working hours. Even though controlling for 'sick leave', 'level of education', 'occupation' and 'industry' may capture important aspects of possible differences in health, working environment, and conditions between the two groups, I find it most likely that they fail to capture all the differences in health, working environment, and conditions. However, despite the fact that offering reduced working hours as a retention measure is a choice made by the individual company, I find it reasonable to assume that older workers are most likely randomly distributed between the intervention and the control companies. Thus, I argue that the health status of the workers, in turn, is most likely randomly distributed and should therefore not influence the results. 
In the search for suitable measures for retaining older workers and to utilize their potential better, the offer of phased retirement may still be part of the answer. In this article I have only investigated whether offering reduced working hours affects the relative risk of withdrawing a full contractual pension. Though my analysis does not support the notion that reduced working hours is a decisive factor for those who choose to opt for full early retirement, my analysis does not shed light on the duration of employment of those who keep on working. A possible next step could be to investigate the impact of offering flexible working hours on the duration of employment of those who do remain in employment.

In any event, there is little doubt that working time flexibility will be on the Norwegian policy agenda in the years to come. Flexibility is a cornerstone of the Norwegian pension reform implemented in 2011, which has made the withdrawal of the old-age pension from National Insurance flexible from the age of 62 for both public- and privatesector workers. Previously, the old age pension was first paid from the age of 67 . For private-sector workers, the contractual pension was also changed to a flexible lifelong annuity and is no longer purely an early-retirement scheme. Pension benefits are also adjusted according to life expectancy. By making these changes to the pension system, policy makers hope to increase the labour supply of older workers in the years to come.

\section{Acknowledgments}

I would like to express my deep gratitude to Professor Espen Dahl and Senior Researcher Tove Midtsundstad, my research supervisors, for their guidance, enthusiastic encouragement, and very useful critiques of this research work.

This article has been financed by The Research Council of Norway as part of the project 'Senior Policy for Whom? The Distributional Consequences and Effects of Initiatives to Promote Active Ageing 218364'. 


\section{References}

Angrist, J. D., \& Pischke, J. S. (2008). Mostly harmless econometrics: An empiricist's companion. Princeton: Princeton University Press.

Becken, L.E. (2011). Redusert arbeidstid med full lønnskompensasjon blant seniorer med rett til AFP i fire statlige etater [Reduced working time with full-income compensation among seniors with the right to early retirement in four state agencies]. Søkelys på arbeidslivet [Spotlight on working life], 28(4): 374-393.

Boockmann, B., Fries, J., \& Göbel, C. (2012). Specific measures for older employees and late career employment Discussion papers: Institut für Angewandte Wirtschaftsforschung (IAW).

Börsch-Supan, A., Brugiavini, A., \& Croda, E. (2009). The role of institutions and health in European patterns of work and retirement. Journal of European social policy, 19(4), 341-358.

Bredgaard, T., \& Tros, F. (2006). Alternatives to early retirement? Flexibility and security for older workers in the Netherlands, Denmark, Germany and Belgium. Paper presented at the ILP Meeting 'Innovating Labour Market Policies: Transitional Labour Markets and Flexicurity', Amsterdam, 30 November-1 December 2006.

Buchholz, S., Hofäcker, D., \& Blossfeld, H.P. (2006). Globalization, accelerating economic change and late careers. A theoretical framework. In H.P. Blossfeld, S. Buchholz \& D. Hofäcker, Globalization, Uncertainty and Late Careers in Society, (pp. 1-23). London/New York: Routledge.

Calvo, E., Sarkisian, N., \& Tamborini, C. R. (2013). Causal Effects of Retirement Timing on Subjective Physical and Emotional Health. The Journals of Gerontology Series B: Psychological Sciences and Social Sciences, 68(1), 73-84.

Charles, K. K., \& DeCicca, P. (2007). Hours flexibility and retirement. Economic Inquiry, 45(2), 251-267.

Dalen, E. (2012). Norsk Seniorpolitisk Barometer 2012 Yrkesaktiv befolkning [Norwegian senior political barometer 2012 working population]. Oslo: Ipso MMI.

Delsen, L. (1996). Gradual retirement: Lessons from the Nordic countries and the Netherlands. European Journal of Industrial Relations, 2(1), 55-67.

Disney, R. (1996). Can we afford to grow older? London: MIT Press. 
Dorn, D., \& Sousa-Poza, A. (2010) 'Voluntary'and 'involuntary'early retirement: an international analysis. Applied Economics, 42, 427-438.

Engelhardt, H. (2012). Late careers in Europe: effects of individual and institutional factors. European Sociological Review, 28(4), 550-563.

Esping-Andersen, G. (2000). The sustainability of welfare states into the twenty-first century. International Journal of Health Services, 30(1), 112.

Eurostat. (2014). Unemployment rates of the population aged 25-64 by level of education (tps00066). Retrieved 27.06, from Eurostat http://epp.eurostat.ec.europa.eu/tgm/table.do?tab=table\&init=1 \&langua ge=en\&pcode $=$ tps00066\&plugin $=1$

Gambetta, D. (1987). Were they pushed or did they jump? Individual decision mechanisms in education. Cambridge: Cambridge University Press.

Gielen, A. C. (2009). Working hours flexibility and older workers' labor supply. Oxford economic papers, 61(2), 240-274.

Graf, N., Hofer, H., \& Winter-Ebmer, R. (2011). Labor supply effects of a subsidized old-age part-time scheme in Austria. Journal for Labour Market Research, 44(3), 217-229.

Gruber, J., \& Wise, D. A. (2007). Social security programs and retirement around the world: Fiscal implications of reform. Chicago: University of Chicago Press.

Gruber, J., \& Wise, D. A. (2010). Social security programs and retirement around the world: the relationship to youth employment. Chicago: University of Chicago Press.

Gustman, A. L., \& Steinmeier, T. L. (2004). Minimum hours constraints, job requirements and retirement. NBER Working Paper No. 10876.

Gørtz, M. (2012). Early retirement in the day-care sector: the role of working conditions and health. European Journal of Ageing, 9(3), 187-198.

Hallberg, D. (2007). Äldres arbetsutbud och möjligheter till sysselsättning, en kunskapsöversikt [Older people's laboursupply and employment opportunities, a summary of knowledge], DS 2007: 21, Ministry of Finance, Sweden.

Halvorsen, K. (1977). Arbeid eller trygd? [Work or social insurance?]. Oslo: Pax.

Hank, K. (2004). Effects of early life family events on women's late life labour market behaviour: an analysis of the relationship between childbearing 
and retirement in Western Germany. European Sociological Review, 20(3), 189-198.

Hauge, L., \& Årethun, T. (2008). Kven går av med AFP? [Who retires on AFP?] NAV-rapport nr. 3. Oslo: Seksjon for statistikk og utredning, Arbeids- og velferdsdirektoratet.

Hernæs, E., Røed, K., \& Strøm, S. (2002). Yrkesdeltakelse, pensjoneringsadferd og økonomiske insentiver [Work participation, retirement behaviour, and economic incentives]. Oslo: Stiftelsen Frischsenteret for samfunnsøkonomisk forskning.

Hilsen, A., \& Salomon, R. (2010). Seniorpolitikk-virker virkemidlene? [Senior policy: do the instruments work?] AFI-rapport, 4, 2010.

Hofäcker, D. (2010). Older workers in a globalizing world: an international comparison of retirement and late-career patterns in Western industrialized countries. Cheltenham, England: Edward Elgar Publishing.

Hutchens, R., \& Grace-Martin, K. (2006). Employer willingness to permit phased retirement: why are some more willing than others? Industrial and Labor Relations Review, 525-546.

Jensen, P. H., \& Øverbye, E. (2013). The work-retirement puzzle Down and out - or free at last? (pp. 118). Berlin: Logos Verlag.

Johnson, R. W. (2011). Phased retirement and workplace flexibility for older adults: opportunities and challenges. The ANNALS of the American Academy of Political and Social Science, 638(1), 68-85.

Latulippe, D., \& Turner, J. (2000). Partial retirement and pension policy in industrialized countries. International Labour Review, 139(2), 179-195.

Leiulfsrud, H., Bison, I., \& Jensberg, H. (2005). Social class in Europe. European Social Survey 2002/3. NTNU Samfunnsforskning/NTNU Social Research Ltd.

Lien, O. C. (2013). Få bytter jobb etter fylte 50 år [Few switch jobs after 50 years of age]. Arbeid og velferd [Work and welfare], 1, 37-50.

Meier, V., \& Werding, M. (2010). Ageing and the welfare state: Securing sustainability. Oxford Review of Economic Policy, 26(4), 655-673.

Midtsundstad, T. (2002). AFP-pensjonisten: sliten - eller frisk og arbeidsfør? En analyse av tidlig pensjonering og bruk av AFP i privatsektor [AFP pensioners: tired or healthy and able-bodied? An analysis of early retirement and the use of AFP in the private sector]. Oslo: Forskningsstiftelsen FAFO. 
Midtsundstad, T. (2005a). Ikke nødvendigvis sliten: en analyse av tidligpensjonering og seniorpolitikk $i$ staten [Not necessarily tired: an analysis of early retirement and senior policy in the state sector]. Oslo: Forskningsstiftelsen FAFO.

Midtsundstad, T. (2005b). Årsaker til førtidspensjonering i Norge [Reasons for early retirement in Norway]. Oslo: Senter for seniorpolitikk.

Midtsundstad, T. (2006). Hvordan bidra til lengre yrkeskarrierer? : erfaringer fra norsk og internasjonal forskning om tidligpensjonering og seniortiltak [How to contribute to longer careers? Experiences from Norwegian and international research on early retirement and measures directed at seniors]. Oslo: Forskningsstiftelsen FAFO.

Midtsundstad, T. (2009). Bedre helse, mindre slit og mer familie [Better health, less wear, and more family]. Oslo: Forskningsstiftelsen FAFO.

Midtsundstad, T. (2013). «Pengene eller livet?» Eldres arbeidsmotivasjon og yrkesdeltakelse» ['Money or life?' The eldery's motivation to work and work participation]. In S. Stjernø \& E. Øverbye (Eds.), Arbeidslinja, Arbeidsmotivasjonen og velferdsstaten [Workfare, the motivation to work, and the welfare state] (pp. 159-170). Oslo: Universitetsforlaget.

Midtsundstad, T., \& Bogen, H. (2011). Ulikt arbeid - ulike behov : seniorpolitisk praksis i norsk arbeidsliv [Different work - different needs: senior policy practice in Norwegian working life]. Oslo: Forskningsstiftelsen FAFO.

Midtsundstad, T., Hermansen, Å., \& Nielsen, R. A. (2012). Effects of Companies' Initiatives to Reduce Early Retirement Among Older Workers. Nordic Journal of Working Life Studies, 2(3), pp. 89-108.

Midtsundstad, T., \& Nielsen, R. A. (2013). Arbeid, pensjon eller begge deler? [Work, retirement, or both?]. Oslo: Forskningsstiftelsen FAFO.

Midtsundstad, T., Nielsen, R. A., \& Hermansen, Å. (2012). Tilrettelegging og seniortiltak - påvirker det kommuneansattes sykefravær og tidligpensjonering? [Adaptation and measures directed at seniors: do they affect municipal employees' sick leave and early retirement?] Søkelys på arbeidslivet [Spotlight on working life], 29(1), 130-150.

NAV. (2014). Tabell 3_Helt ledige fordelt på kjønn. Årsgjennomsnitt.1948_2013. [Table 3, Fully unemployed, divided by gender. Yearly average.] Retrieved 27.06, from NAV https://www.nav.no/no/NAV+og+samfunn/Statistikk/Arbeidssokere+og +stillinger+-+statistikk/Historisk+statistikk 
Nergaard, K. (2009). Hvem har ikke AFP? En analyse med basis $i$ registerbaserte data [Who does not have AFP? An analysis with a basis in register-based data]. Oslo: Forskningsstiftelsen FAFO

OECD. (2013). Ageing and Employment Policies: Norway 2013 Working Better with Age. Paris: OECD.

Oude Hengel, K. M., Blatter, B. M., Geuskens, G. A., Koppes, L. L., \& Bongers, P. M. (2012). Factors associated with the ability and willingness to continue working until the age of 65 in construction workers. International Archives of Occupational and Environmental Health, 1-8.

Redaymulvey, G. (2000). Gradual retirement in Europe. Journal of Aging \& Social Policy, 11(2-3), 49-60.

Reichborn-Kjennerud, K., Gamperiene, M., \& Hilsen, A. I. (2011). 'Make me an offer I Can't Refuse' - Do Extra Days off Contribute to Seniors Staying at Work longer? Older Workers in a Sustainable Society: Peter Lang Publishing Group.

Taylor, P. (2006). Employment initiatives for an ageing workforce in the EU15. Luxembourg: The European Foundation for the Improvement of Living and Working Conditions.

Taylor, P. (2011). Is early retirement history? Labour, education \& society, 21, $225-232$

Vickerstaff, S., Cox, J., \& Keen, L. (2003). Employers and the management of retirement. Social policy \& administration, 37(3), 271-287.

Wadensjö, E. (2006). Part-time pensions and part-time work in Sweden. Bonn: The Institute for the Study of Labor.

Wooldridge, J. M. (2005). Fixed-effects and related estimators for correlated random-coefficient and treatment-effect panel data models. Review of Economics and Statistics, 87(2), 385-390.

Wooldridge, J. M. (2009). Introductory econometrics: a modern approach. Mason, $\mathrm{OH}$ : Thomson/South-Western. 